\title{
Are Fallacies Common? A Look at Two Debates
}

\author{
GARY JASON
}

The last decade has seen a healthy debate regarding the nature of fallacies. The "standard textbook account" has been criticised extensively, and new theoretical approaches have been tried, centering around the formal theory of dialogues. The debate has taken on new importance since the recent widespread adoption of "critical thinking" requirements at many colleges.

One aspect of the standard textbook account that has drawn considerable criticism is the claim that fallacies are "commonly made" errors in reasoning. Such a claim has struck some scholars as an exaggeration, or as perhaps merely a motivational remark to induce the student to study harder. Finocchiaro has put this criticism with special sharpness:

What is wrong with such accounts of fallacies? One problem concerns the paucity of actual examples, just mentioned. It is in fact puzzling that logic textbooks shouldn't be able to come up with more examples of fallacies actually committed given that fallacies are supposed to be common errors in reasoning. One gets the suspicion that logically incorrect arguments are not that common in practice, that their existence may be largely restricted to logic textbook examples and exercises.[1]

He concludes:

The conclusion I wish to draw from such "consultations" is not that errors in reasoning are probably not common in real life, but that there probably are no common errors in reasoning. That
Washburn University

is, logically incorrect arguments may be common, but common types of logically incorrect arguments probably are not.[2]

In this article I wish to give empirical evidence that fallacies are indeed common. I will use the term "fallacy" to mean the sort of errors in argumentation labelled in standard logic texts. Whether the standard definitions should be altered or clarified by means of formal dialectic is a question I won't address here.

It would be wise to get clear on what the claim "fallacies are common" really involves. Clearly, nobody means to suggest that fallacies occur commonly in all aspects of our daily lives. Most of the waking hours of most people are spent on entertainment, transportation, recreation and so on. Fallacies aren't common in such activities, for the trivial reason that no argumentation bad or good takes place in those activities. If we are to fairly test the claim that fallacies are common, we must focus on contexts of argumentative persuasion.

In the realm of literature, focusing upon contexts of argumentative persuasion generally rules out fiction, and a good deal of nonfiction as well. After all, most mainstream newspapers tend to simply describe events, except in the Op/Ed pages. Quite a bit of nonfiction is devoted to simply explaining current developments in, say, science or art.

What then are clear contexts of argumentative persuasion? The reader's list 
may differ from mine, but I would include: advertisements, editorials, position papers, essays, letters to editor, debates, and books and articles that advocate some position. It is those sorts of contexts to which the claim that fallacies are common is meant to apply.

It is easy to get the impression that fallacies are common if one reads scientific or philosophic journals or books. Such literature is by its very nature closely reasoned. Even if fallacies are not commonly present in such writings, that doesn't mean that fallacies are not common; rather, it only shows that careful reasoners can avoid what are otherwise errors in reasoning. Indeed, those of us who teach the standard material hope that eventually those fallacies will become uncommon precisely because people will become more careful thinkers.

But it is equally easy to get the impression that not only are fallacies common, but nonfallacious reasoning is uncommon, if one reads the tabloids. The National Enquirer is the best selling newspaper in the U.S.A., and its numerous clones also sell well. The typical issue of such a tabloid is loaded with fallacies of the traditional sort: ads which appeal to popular sentiment or contain fallacious appeals to authority ("this diet is doctor-tested!"); editorials filled with invective, personal attacks and loaded language; amphibolous headlines intended to make uninteresting stories interesting ("NUN WALKS HUNDREDS OF MILES - TO LOSE WEIGHT!" screams the headline, while the story describes a perfectly banal case of a nun who walks several blocks every evening for exercise, and over the years it adds up to hundreds of miles); ads with key clauses put in fine print ("accent"); and so on.

However, if the claim that fallacies are common is to be fairly tested, we ought to avoid extremes-contexts either expecially "clean" or especially "dirty." If the claim that fallacies are common is taken fairly, it clearly is meant to apply to ordinary contexts of argumentative persuasion: $\mathrm{Op} / \mathrm{Ed}$ newsmagazines; letters to the editor of good quality newspapers, newsmagazines, political opinion journals (such as National Review, New Republic, Atlantic and so on), and other nonfiction magazines (such as Byte, Car and Driver, and so on); political debates; position papers; and so on.

I propose to empirically investigate the claim that fallacies as standardly defined are common by selecting a fair context of argumentative persuasion, one that is clearly of influence on the opinions of millions of Americans: political debates. Political debates are quite common in American political life. One thinks immediately of classical debates such as the ones between Lincoln and Douglas, but of course such debates have had even wider impact since being televised (starting with the Nixon/Kennedy debates, then moving on to the Carter/Ford, then Carter/Reagan, then Reagan/Mondale debates). To make this investigation more useful, we will look at two debates, separated widely in time but similar in importance: the third Kennedy/Nixon debate (held on October 13, 1960) and the second Reagan/Mondale debate (held on October 21, 1984). Both debates were very important in the respective elections; indeed, both resulted in turnarounds in the polls for the candidates who eventually won their respective races. In what follows, I will select fallacies falling in certain recurring categories for commentary, rather than reproducing the whole debates. While each debate has between forty and fifty readily identifiable standard fallacies, I have tried to select the most instructive for analysis. If the reader suspects me of having been biased in my selection, 1 am willing to send him transcripts of both debates with the numerous fallacies indicated.

\section{Fallacies of Ignoring the Issue}

In examining the texts of the two debates, one is immediately struck by the large number of times in which the candidates ignore the issue. Some 
Mr. Nixon: Now, looking to the U-2 flights, I would like to point out that I have been supporting the President's position throughout. I think the President was correct in ordering these flights. I think the President was correct, certainly, in his decision to continue the flights while the conference was going on. I noted, for example, in reading a particular discussion that Senator Kennedy had with Dave Garroway shortly after the uh - his statements about regrets, that uh-he made the statement that he felt that these particular flights were ones that shouldn't have occurred right at that time, and the indication was how would Mr. Khrushchev had felt if we had had a flight over the United States while he was visiting here. And the answer, of course, is that Communist espionage goes on all the time. The answer is that the United States can't afford to have an espionage lack-or should I say an intelligence lag-any more than we can afford to have a missile lag.

It is clear from the passage that Kennedy had raised the issue of whether $\mathrm{U}$ 2 flights should have been conducted while Khrushchev was visiting here, and Nixon addressed the different issue of whether the US should engage in espionage. I don't think I am being uncharitable in interpreting Nixon's remarks as having evaded the issue; indeed, Kennedy rebutted him shortly after Nixon made his comment:

Mr. Kennedy: Number two, on the question of the U-2 flights. I thought the U-2 flights in May just before the conference was a mistake in timing because of the hazards involved, if the summit conference had any hope for success. I never criticized the U-2 flights in general, however. I never suggested espionage should stop. It still goes on, I would assume, on both sides.

In the example above, the candidate ignored the issue by "setting up a strawman" - that is, distorting his opponent's position. Also common in the debates are cases in which candidates did not answer the questions put to them, but instead raised irrelevant issues or reverted to earlier issues.
Mr. McGee: Mr. Vice President, some of your early campaign literature said you were making a study to see if new laws were needed to protect the public against excessive use of power by labor unions. Have you decided whether such new laws are needed, and, if so, what would they do?

Mr. Nixon: Mr. McGee, I am planning a speech on that subject next week. Also, so that we can get the opportunity for the questioners to question me, it will be before the next television debate. I will say simply, in advance of it, that I believe that in this area, the laws which shouid be passed, as far as the big national emergency strikes are concerned, are ones that will give the president more weapons with which to deal with those strikes. Now, I have a basic disagreement with Senator Kennedy, though, on this point. He has taken the position, when he first indicated in October of last year, that he would even favor compulsory arbitration as one of the weapons the president might have to stop a national emergency strike. I understand in his last speech before the Steelworkers Union, that he changed that position and indicated that he felt that government seizure might be the best way to stop a strike which could not be settled by collective bargaining. I do not believe we should have either compulsory arbitration or seizure. I think the moment that you give to the union, on the one side, and to management, on the other side, the escape hatch of eventually going to government to get it settled, that most of these great strikes will end up being settled by government, and that will be in the end, in my opinion, wage control; it would mean price control-all the things that we do not want. I do believe, however, that we can give to the president of the United States powers, in addition to what he presently has in the fact-finding area, which would enable him to be more effective than we have been in handling these strikes.

Nixon does not answer the question whether he would propose new laws restricting the power of unions, and if so, which ones. He says he will give a speech the next week on the subject, he criticizes Kennedy's position on compulsory arbitration, but aside from say- 
ing that the President needs greater powers to deal with "national emergency strikes," he says nothing. Speaking in generalities is one way candidates ignore the specific issue raised by a questioner. Another example:

Mr. McGeo: Senator Kennedy, a moment ago you mentioned tax loopholes. Now your running mate, Senator Lyndon Johnson, is from Texas, an oilproducing state and one that many political leaders feel is in doubt in this election year. And reports from there say that oil men in Texas are seeking assurance from Senator Johnson that the oil depletion allowance will not be cut. The Democratic platform pledges to plug loopholes in the tax laws and refers to inequitable depletion allowance as being conspicuous loopholes. My question is, do you consider the twentyseven and a half percent depletion allowance inequitable, and would you ask that it be cut?

Mr. Kennedy: Mr. McGee, there are about a hundred and four commodities that have some kind of depletion allowance-different kinds of minerals, including oil. I believe all of those should be gone over in detail to make sure that no one is getting a tax break; to make sure that no one is getting away from paying the taxes he ought to pay. That includes oil; it includes all kinds of minerals; it includes everything within the range of taxation. We want to be sure it's fair and equitable. It includes oil abroad. Perhaps that oil abroad should be treated differently than the oil here at home. Now the oil industry recently has had hard times. Particularly some of the smaller producers. They're moving about eight or nine days in Texas. But 1 can assure you that if $1 \mathrm{\prime m}$ elected president, the whole spectrum of taxes will be gone through carefully, and if there is any inequities in oil or any other commodity, then I would vote to close that loophole. I have voted in the past to reduce the depletion allowance for the largest producers; for those from five million dollars down, to maintain it at twenty-seven and a half percent. I believe we should study this and other allowances; tax expense, dividend expenses and all the rest, and make a determination of how we can stimulate growth; how we can provide the revenues needed to move our country forward.

Note that Kennedy never specifically answered the questions whether the present $271 / 2 \%$ depletion allowance is inequitable and whether he would cut it. In many of their other answers, Kennedy and Nixon ascended to generalities.

Ignoring the issue was a prominent feature of the Reagan/Mondale debate -occuring fifteen times or more. Again, some examples:

Q. Mr. Mondale, two related questions on the crucial issue of Central America. You and the Democratic Party have said that the only policy toward the horrendous civil wars in Central America should be on the economic developments and negotiations with, perhaps, a quarantine of Marxist Nicaragua. Do you believe that these answers would in any way solve the bitter conflicts there? Do you really believe that there is no need to resort to force at all? Are not these solutions to Central America's gnawing problems simply again too weak and too late?

Mondale: I believe that the question oversimplifies the difficulties of what we must do in Central America. Our objectives ought to be to strengthen the democracy, to stop Communist and other extremist influences and stabilize the community in that area.

To do that, we need a three-pronged attack. One is military assistance to our friends who are being pressured. Secondly, a strong and sophisticated economic aid program and human rights program that offers a better life and a sharper alternative to the alternative offered by the totalitarians who oppose us. And finally, a strong diplomatic effort that pursues the possibilities of peace in the area.

The crucial question about whether military force is needed was never specifically addressed. Instead, Mondale spoke in generalities.

Q. Mr. Mondale, if I could broaden the question just a little bit. Since World War II, every conflict that we as Americans have been involved with has been in nonconventional or irregular terms 
and yet we keep fighting in conventional or traditional military terms. The Central American wars are very much in the same pattern as China, as Lebanon, as Iran, as Cuba in the early days. Do you see any possibility that we are going to realize the change in warfare in our time or react to it in those terms?

Mondale: We absolutely must, which is why I responded to your first question the way I did. It's much more complex. You must understand the region, you must understand the politics in the area, you must provide a strong alternative, and you must show strengthand all at the same time. That's why I object to the covert action in Nicaragua. That's a classic example of a strategy that's embarrassed us, strengthened our opposition and undermined the moral authority of our people and our country in the region.

Again, Mondale ignores the central question (which was how the U.S. should handle unconventional wars) by speaking in glittering generalities.

Q. Mr. President, | want to ask you about negotiating with friends. You severely criticized President Carter for helping to undermine two friendly dictators who got into trouble with their own people, the Shah of Iran and President Somoza of Nicaragua. Now there are other such leaders heading for trouble, including President Pinochet of Chile and President Marcos of the Philippines. What should you do and what can you do to prevent the Phillppines from becoming another Nicaragua?

Reagan: Morton, I did criticize the President because of our undercutting of what was a stalwart ally, the Shah of Iran. And I am not at all convinced that he was that far out of line with his people or that they wanted that to happen.

The Shah had done our bidding and carried our load in the Middle East for quite some time and $I$ did think that it was a blot on our record that we let him down. Had things gotten better, the Shah, whatever he might have done, was building low-cost housing, had taken land away from the mullahs and was distributing it to the peasants so they could be land-owners, things of that kind. But we turned it over to a maniacal fanatic who has slaughtered thousands and thousands of people calling it executions.

The matter of Somoza, no, I never defended Somoza. And as a matter of fact, the previous Administration stood by and so did I-not that I could have done anything in my position at that time. But for this revolution to take place and the promise of the revolution was democracy, human rights, free labor unions, free press. And then just as Castro had done in Cuba, the Sandinistas ousted the other parties to the revolution. Many of them are now the Contras. They exiled some, they jailed some, they murdered some. And they installed a Marxist-Leninist totalitarian Government.

And what I have to say about this is, many times-and this has to do with the Philippines also-1 know there are things there in the Philippines that do not look good to us from the standpoint right now of democratic rights. But what is the alternative? It is a large Communist movement to take over the Philippines.

They have been our friend for-since their inception as a nation. And I think that we've had enough of a record of letting, under the guise of revolution, someone that we thought was a little more right than we would be, letting that person go and then winding up with totalitarianism pure and simple as the alternative and I think that we're better off, for example, with the Philippines of trying to retain our friendship and help them right the wrongs we see rather than throwing them to the wolves and then facing a Communist power in the Pacific.

Note that Reagan ignores the issue of what he would do to prevent the Philippines from becoming another Nicaragua.

Why do candidates so often ignore the issues raised by the interviewers and the opposing candidates? Here we must remind ourselves that attributing a fallacy to someone is not necessarily to accuse that person of dishonest argu- 
mentation. A fallacy is an error in argumentation but not necessarily a dishonest or deliberate one. In a sense, political candidates in a televised debate are prisoners of the format. They cannot say "I don't know, I'll have to think about it" to a new and difficult issue. Nor can they tell an interviewer that his question is hopelessly naive, impertinent, assinine, unfairly specific, or ridiculously broad, for fear of appearing churlish. The fault for such logical lapses may lie not in our politicians but in ourselves, for making up our minds about for whom to vote on the basis of one or two short debate performances.

However, one might argue that political candidates are not completely compelled to ignore the issue when asked a question whose fully detailed answer would take much more than the time alloted. For instance, perhaps the candidates could sketch out a general answer, and then indicate which of the position papers he has issued amplify upon his views. But there are difficulties with such a suggestion. It is hard for candidates to anticipate in advance all the issues upon which questions will be asked, and so it would be hard for them to issue position papers in advance. And any candidate who promises to issue a paper only after the debate is over is likely to appear foolish. But perhaps some other means can be devised to allow candidates to really grapple with complicated issues.

\section{False Cause}

In reading the transcripts of the debates, one is struck also by the number of times one candidate $A$ will argue that since bad things happened when the other candidate B (or his party) was in office, B was the cause of those bad things, or that since good things happened while $A$ (or his party) was in office, A was the cause of those good things. Such arguments are fallacies of false cause (specifically post hoc ergo propter hoc). Examples:

Mr. Nixon: Yes. As a matter of fact, the statement that Senator Kennedy made was that-to the effect that there were trigger-happy Republicans, that my stand on Quemoy and Matsu was an indication of trigger-happy Republicans. I resent that comment. I resent it because it's an implication that Republicans have been trigger-happy and, therefore, would lead this nation into war. I would remind Senator Kennedy of the past fifty years. I would ask him to name one Republican president who led this nation into war. There were three Democratic presidents who led us into war. I do not mean by that that one party is a war party and the other party is a peace party. But $I$ do say that any statement to the effect that the Republican party is trigger-happy is belied by the record.

We might interpret this passage charitably by taking Nixon's statement "I do not mean by that that one party is a war party..." at face value; however, since Republicans such as Ford, Dole, and Bush have made the same point in later debates (that all wars in this century were started under Democratic presidents), I think we may fairly suspect that Nixon was attempting to paint the Democrats as being responsible for wars

Mr. Nixon. One last point I should make. The record in handling strikes has been very good during this Administration. We have had less manhours lost by strikes in these last seven years than we had in the previous seven years, by a great deal. And I only want to say that however good the record is, it's got to be better. Because in this critical period of the sixties we've got to move forward, all Americans must move forward together, and we have to get the greatest cooperation possible between labor and management. We cannot afford stoppages of massive effect on the economy when we're in the terrible competition we're in with the Soviets.

A fair construal of Nixon's remarks is that since fewer man-hours were lost by strikes during the Republican administration, it (and by some further infe- 
rence, he) therefore should be given credit. But any number of other factors may be the cause of reduced strike activity (besides the administration's policies). Indeed, under the American economic system, the President and his administration have little to do with wage union activities and corporate decisions.

Mr. Kennedy. On the question of the cost of our budget, I have stated that it's my best judgment that our agricultural program will cost a billion and a halt, possibly two biltion dollars less than the present agricultural program. My judgment is that the program the Vice President put forward, which is an extension of Mr. Benson's program, will cost a billion dollars more than the present program, which costs about six billion dollars a year, the most expensive in history. We've spent more money on agriculture in the last eight years than the hundred years of the Agricultural Department before that.

A fair construal of Kennedy's remarks is that because more money has been spent on Agriculture during the years while the Republicans were in the White House, they must be responsible for that increased spending. But again, other factors (such as Congressional actions) may have been the actual cause of the increase. Indeed, at the federal level, the President does not have lineitem veto: he must either veto the budget as a whole (which can lead to great economic disruptions), or approve it. That limits a President's power to control spending considerably. Moreover (again-in the American system), it is not unusual for one political party to control the White House and the other party the Congress (where spending bills originate). That also dramatically limits a President's power to control spending. So merely pointing out that spending increased under $x$ 's administration does not come anywhere near showing that $x$ is responsible for it.

Mr. Nixon: I am never satisfied with the economic growth of this country. I'm not satisfied with it even if there were no Communism in the world, but particularly when we're in the kind of a race we're in, we have got to see that America grows just as fast as we can, provided we grow soundly. Because even though we have maintained, as 1 pointed out in our first debate, the absolute gap over the Soviet Union; even though the growth in this Administration has been twice as much as it was in the Truman Administration; that isn't good enough. Because America must be able to grow enough not only to take care of our needs at home for better education and housing and health-all these things we want.

Nixon asserts that he won't be content with the growth rate achieved under the current Republican administration, even though it is double the rate in the previous (Democratic) administration. It is reasonable to view this passage as containing the enthymeme that because under the Republican administration the growth rate was double what it was under the Democratic one, that the Republicans are responsible for the higher rate. Later in the debate, Nixon reiterated the argument:
American has not been standing still.
Let's get that straight. Anybody who says American's been standing still for the last seven and a half years hasn't been traveling around America. He's been traveling in some other country. We have been moving. We have been moving much faster than we did in the Truman years. But we can and must move faster, and that's why I stand so strongly for programs that will move America forward in the six- ties, move her forward so that we can stay ahead of the Soviet Union and win the battle for freedom and peace.

An example from the Reagan/Mondale debate:

Mr. Mondale: Where I part with the President is that despite all of those differences, we must, as past Presidents before this one have done, meet on the common ground of survival.

And that's where the President has opposed practically every arms control 
agreement, by every President of both political parties, since the bomb went off.

And he now completes this term with no progress toward arms control at all, but with a very dangerous arms race underway instead.

There are now over 2,000 more warheads pointed at us today than there were when he was sworn in, and that does not strengthen us.

Mondale seems to be arguing that since there have been no arms control agreements under Reagan, Reagan must be the cause. But other causes are possible; for instance, the instability in the Soviet government (several Soviet Premiers died during Reagan's first term). Perhaps we should be very charitable and say that Reagan's hawkish statements and affiliations are well-known, and that Mondale is rightly appealing to background knowledge. But even granting that that is truly uncontested background knowledge (which I suspect Reagan and his supporters would vigorously deny), it still does not come near proving that Reagan is responsible for the lack of agreements on arms. Some hawks have signed arms agreements (e.g., Nixon), and some doves have failed (e.g., Kennedy, who got a partial test ban but no arms limitations treaty). At the very least, Mondale needed to point to specific proposals made in good faith by the Soviets which Reagan refused to consider, or specific occasions where the Soviets were willing to negotiate and Reagan wasn't. Perhaps Mondale could have done so, but what he said did not constitute proof, but only a false cause fallacy.

In the following exchange, several instances of false cause were committed.

Mondale: One of the biggest problems today is that the countries to our south are so desperately poor that these peo. ple who will almost lose their lives if they don't come north, come north despite all the risks. And if we're going to find a permanent, fundamental answer to this, it goes to American economic and trade policies that permit these nations to have a chance to get on their own two feet and to get prosperity so that they can have jobs for themselves and their people.

And that's why this enormous national debt, engineered by this Administration, is harming these countries and fueling this immigration.

These high interest rates, real rates, that have doubled under the Administration, have had the same effect on Mexico and so on, and the cost of repaying those debts is so enormous that it results in massive unemployment, hardship and heartache. And that drives our friends to the northto the south-up into our region, and the need to end those deficits as well.

Moderator: Mr. President, your rebuttal.

Reagan: Well, my rebuttal is I've heard the national debt blamed for a lot of things, but not for illegal immigration across our border, and it has nothing to do with it.

But with regard to these high interest rates, too, at least give us the recognition of the fact that when you left office, Mr. Mondale, they were $221 / 2$, the prime rate; it's now $121 / 4$, and I predict it'll be coming down a little more shortly. So we're trying to undo some of the things that your Administration did.

The national debt grew under Reagan, so Reagan caused it (and that, curiously, caused the illegal immigration from Mexico!), to which Reagan responds by saying that the interest rates were high under Carter, so Carter caused that problem (and so, curiously, that Mondale is to blame).

Again, we must be fair and realize that giving a candiate one minute to explain what causes (say) high interest rates is not a way to encourage indepth causal analysis.

\section{Ad populum}

Quite unsurprising is the large number of appeals to patriotism, "usversus-them" emotions and so on. These sorts of appeals are apparent in 
many of the sample passages cited earlier (especially in the passages appealing to our collective fear of the Soviets). Some additional examples:

\begin{abstract}
Mr. Nixon: Now what do the Chinese Communists want? They don't want just Quemoy and Matsu; they don't want just Formosa; they want the world. And the question is if you surrender or indicate in advance that you're not going to defend any part of the free world, and you figure that's going to satisfy them, it doesn't satisfy them. It only whets their appetite; and then the question comes, when do you stop them? l've often heard President Eisenhower in discussing this question, make the statement that if we once start the process of indicating that this point or that point is not the place to stop those who threaten the peace and freedom of the world, where do we stop them? And I say that those of us who stand against surrender of territorythis or any others - in the face of blackmail, in the face of force by the Communists are standing for the course that will lead to peace.
\end{abstract}

In this passage, Nixon associates himself with the popular President Eisenhower, and places himself in the class of those who oppose Communistic blackmail, who favor peace-in short, places himself on the side of the angels (and Ike!). There is also arguably a slippery-slope fallacy lurking in the passage: if we do not defend Quemoy and Matsu, we don't know where they will stop.

Mr. Nixon: Beyond that, as far as the gold supply is concerned, and as far as the movement of gold is concerned, we have to bear in mind that we must get more help from our allies abroad in this great venture in which all tree men are involved of winning the battle for freedom.

Again, grandiose appeals to freedom used to (somehow) buttress a position.

Mr. Nixon: Of course, both Senator Kennedy and I have felt Mr. Truman's ire; and consequently, I think he can speak with some feeling on this subject. I just do want to say one thing, however. We all have tempers; I have one; I'm sure Senator Kennedy has one. But when a man's president of the United States, or a former president, he has an obligation not to lose his temper in public. One thing l've noted as I've traveled around the country are the tremendous number of children who come out to see the presidential candidates. I see mothers holding their babies up, so that they can see a man who might be president of the United States. I know Senator Kennedy sees them, too. It makes you realize that whoever is president is going to be a man that all the children of America will either look up to, or will look down to. And I can only say that I'm very proud that President Eisenhower restored dignity and decency and, frankly, good language to the conduct of the presidency of the United States. And I only hope that, should I win this election, that I could approach President Eisenhower in maintaining the dignity of the office; in seeing to it that whenever any mother or father talks to his child, he can look at the man in the White House and, whatever he may think of his policies, he will say: "Well, there is a man who maintains the kind of standards personally that I would want my child to follow."

Nixon paints a picture of mothers holding babies looking up to a clean role-model, the immensely popular Eisenhower, and clearly hopes the audience will transfer those warm respectful feelings to him.

The closing statements in the Reagan/Mondale debate also brought out some appeal to the crowd. Two short examples:

Mr. Mondale: I want this nation to protect its air, its water, its land and its public health. America is not temporary. We're forever. And as Americans, our generation should protect this wonderful land for our children.

I want a nation of fairness, where no one is denied the fullness of life or discriminated against, and we deal compassionately with those in our midst who are in trouble.

And above all, I want a nation that's strong. Since we debated two weeks ago, the United States and the Soviet Union have built 100 more warheads, enough to kill millions of Americans and millions of Soviet citizens. 
Mr. Reagan: We shouldn't be dwelling on the past or even the present. The meaning of this election is the future, and whether we're going to grow and provide the jobs and the opportunities for all Americans and that they need. Several years ago I was given an assignment to write a letter. It was to go into a time capsule and would be read in 100 years when that time capsule was opened. I remember driving down the California coast one day. My mind was full of what I was going to put in that letter about the problems and the issues that confront us in our time and what we did about them, but I couldn't completely neglect the beauty around me-the Pacific out there on one side of the highway shining in the sunlight, the mountains of the coast range rising on the other side, and I found myself wondering what it would be like for someone, wondering if someone 100 years from now would be driving down that highway and if they would see the same thing.

The reader should not interpret my remarks as saying that only deceitful politicians would stoop to ad populum appeals. No, even very decent politicians engage in such rhetoric. But ad populum appeals should be recognized as such, even if we condone their usage in contexts such as the one under consideration.

\section{Ad hominem Attacks}

Less frequent in the two debates are overt ad hominem attacks. I found this surprising, given how frequently personal attacks occur in ordinary arguments and letters to the editor of magazines and newspapers. Perhaps candidates in a nationally televised debate are reluctant to attack the other too blatantly, lest the debate turn into a mudslinging contest. But sly digs are managed:

Mr. Kennedy: Mr. Griffin, I believe, who is the head of the Klan, who lives in Tampa, Florida, indicated in a statement, I think, two or three weeks ago that he was not going to vote for me, and that he was going to vote for $\mathrm{Mr}$. Nixon. I do not suggest in any way, nor have I ever, that that indicates that $\mathrm{Mr}$. Nixon has the slightest sympathy, involvement, or in any way imply any inference in regard to the Ku Klux Klan. That's absurd. I don't suggest that. I don't support it. I would disagree with it.

Kennedy protests too much -- he himself brings up the fact that the head of the KKK came out in support of Nixon, and it is not uncharitable, I think, to believe that Kennedy was suggesting that since the $K K K$ supported Nixon, Nixon was suspect (guilt by association).

Mr. Nixon: [ responding to Kennedy's point that the U.S. had slipped in prestige, as evidenced by Gallup polls taken in other countries, and U.N. votes]: Well, I would say first of all that Senator Kennedy's statement that he's just made is not going to help our Gallup Polls abroad and it isn't going to help our prestige either. Let's look at the other side of the coin. Let's look at the vote on the Congo, the vote was seventy to nothing against the Soviet Union. Let's look at the situation with regard to economic growth as it really is. We find that the Soviet Union is a very primitive economy. Its growth rate is not what counts; it's whether it is catching up with us and it is catching up with us. We're well ahead and we can stay ahead, provided we have confidence in America and don't run her down in order to build her up. We could look also at other items which Senator Kennedy has named, but I will only conclude by saying this: in this whole matter of prestige, in the final analysis, it's whether you stand for what's right. And getting back to this matter that we discussed at the outset, the matter of Quemoy and Matsu. I can think of nothing that will be a greater blow to the prestige of the United States among the free nations in Asia than for us to take Senator Kennedy's advice to go against what a majority of the members of the Senate, both Democrat and Republican, did-said in 1955, and to say in advance we will surrender an area to the Communists.

Nixon insinuates that Kennedy's point is suspect because it hurts our reputation, and that those who want America held in high regard should avoid such 
comments.

Other standard fallacies are discernible in the two debates, including loaded questions (by the questioners), appeals to authority, false analogies, slippery slope arguments, and hedging. I found no cases of composition or division, and only one rather unclear case of begging the question.

Some of the candidates-Kennedy and Reagan, in particular-deflected questions by humorous diversion. It is plausible to suggest that those candidates who are by nature witty will utilize their wit to get out of answering questions they don't wish to answer (for whatever reasons). Example:

Mr. Von Fremd: Senator Kennedy, I'd like to shift the conversation, if I may, to a domestic political argument. The chairman of the Republican National Committee, Senator Thurston Morton, declared earlier this week that you owed Vice President Nixon and the Republican party a public apology for some strong charges made by former President Harry Truman, who bluntly suggested where the Vice President and the Republican party could go. Do you feel that you owe the Vice President any apology?

Mr. Kennedy: Well, I must say that Mr. Truman has his methods of expressing things; he's been in politics for fifty years; he's been President of the United States. They are not my style. But 1 really don't think there's anything that I could say to President Truman that's going to cause him, at the age of seventy-six, to change his particular speaking manner. Perhaps Mrs. Truman can, but I don't think I can. I'll just have to tell Mr. Morton that. If you'd pass that message on to him.

Moderator: Mr. Trewhitt, your question to President Reagan?

Q. Mr. President, I want to raise an issue that I think has been lurking out there for two or three weeks, and cast it specifically in national security terms. You already are the oldest President in history, and some of your staff say you were tired after your most recent encounter with Mr. Mondale. I recall, yes, that President Kennedy, who had to go for days on end with very little sleep during the Cuba missile crisis. Is there any doubt in your mind that you would be able to function in such circumstances?

Reagan: Not at all, Mr. Trewhitt and I want you to know that also I will not make age an issue of this campaign. I am not going to exploit for political purposes my opponent's youth and inexperience.

If I still have time, I might add, $\mathrm{Mr}$. Trewhitt, I might add that it was Seneca or it was Circero, I don't know which, that said if it was not for the elders correcting the mistakes of the young, there would be no state.

Q. Mr. President, l'd like to head for the fence and try to catch that one before it goes over but - without going to another question.

This was perhaps the most famous moment in the Reagan/Mondale debate. The President turned aside Trewhitt's question with a quip which made everyone including Mondale laugh, and did much to defuse the "age issue." The questioner, Mr. Trewhitt, realized that the President had scored a home run on that pitch!)

In both the debates examined, roughly forty to fifty standard fallacies are discernible, without, it must be admitted, being overly charitable. The numbers are reduced if we bend over backwards to be charitable, but the clear fallacies are still sufficiently numerous to justify the claim that the standard fallacies discussed in "old time" logic texts are indeed common. A student who read Whately's Elements of Logic would have no trouble applying the definitions of fallacies contained therein to the debates we have been examining.

Not only do fallacies as standardly defined seem common, but it seems likely that we can empirically correlate type of fallacy with type of argumentative context. Political debates seem to call forth ignoring the issue and ad populum arguments. Sales pitches seem to involve special pleading. However, much more empirical work needs to be done to say for sure.

It is hard enough to teach standard 
introductory logic well when one has confidence that what he teaches truly edifies the student. Let us not lose confidence by supposing that traditional categories of logical error, seemingly discerned by scholars of many different cultures over millenia, are in fact an illusion.

Notes

[1] Maurice Finocchiaro "Fallacies and the Evaluation of Reasoning," American Philosophical Quarterly, Vol. 18, No. 1, Jan. 1981, p. 14.

[2] Ibid.p. 15.

Professor Gary Jason, Department of Philosophy, Washburn University of Topeka, Topeka, KA 66621 